\title{
Karmetkombinat: history of construction and environmental problems
}

\author{
Zauresh Saktaganova ${ }^{1}$, Zhanna Mazhitova ${ }^{2 *}$, Aiman Azmukhanova ${ }^{3}$, and Kenzhegul \\ Zhussupova $^{4}$ \\ ${ }^{1}$ Buketov Karaganda State University, Karaganda, Republic of Kazakhstan \\ ${ }^{2}$ Astana Medical University, Nur Sultan, Republic of Kazakhstan \\ ${ }^{3}$ L.N. Gumilyov Eurasian National University, Nur Sultan, Republic of Kazakhstan \\ ${ }^{4}$ Asfendiyarov Kazakh National Medical University, Almaty, Republic of Kazakhstan
}

\begin{abstract}
This article examines the history of the Karaganda metallurgical plant construction. The authors emphasize that the issue of building large objects of heavy industry for the war effort became urgent during the Great Patriotic War. Due to the fact that Kazakhstan possessed large minerals reserves, in 1942 in the Karaganda region the People's Commissariat of Ferrous Metallurgy of the USSR initiated the construction of a metallurgical plant for the production of iron, steel and rolled products. However, the start of the plant construction was delayed for several years. First of all, the delay was due to the fact that the plant site, construction base, railway tracks were not prepared for operation for a long time. In addition, the construction of the Atasu iron mine, which was the ore base of the plant, was carried out at a slow pace. Only in 1957, the project of the Karaganda Metallurgical Plant was approved by the Government of the USSR. The authors note that in 1958 the plant became an all-Union Komsomol construction site, in the construction of which seven specialized enterprises participated. The modern Karmetkombinat is one of the largest metallurgical and coal bases in the republic. At the same time, it gives rise to a complex of environmental problems in the region, the solution of which remains permanent.
\end{abstract}

\section{Introduction}

The entry of the Kazakh lands into the Russian Empire led to a gradual penetration of capitalist relations into the region, which made many changes in the socio-cultural and economic life of the local population [1]. In the 19th century new industries were developed in Kazakhstan including coal mining in the Karaganda region, oil fields in Western Kazakhstan [2]. It can be said that from that moment the active development of the Karaganda deposits began. During the Soviet period, the region developed dynamically and invariably attracted the attention of scientists and researchers, since it possessed huge reserves of minerals that were so necessary for the industrial development of the young Soviet state [3].

\footnotetext{
* Corresponding author: mazhitova69@mail.ru
} 
The modern Karaganda region is one of the leading industrial regions of Kazakhstan. The industry specializing in the production of energy and material-intensive products of ferrous metallurgy, the production of non-ferrous metals, the extraction of coal and ores of a number of valuable minerals has been formed here. The Karaganda region is unique in Kazakhstan in terms of its impact on the environment. There are well-developed enterprises in the food industry, mechanical engineering and metalworking enterprises, production of building materials, chemical industry, production of rubber and plastic products, etc. The Karaganda region accounts for almost a quarter (23.7\%) of the republic's manufacturing industry, which is due to the predominant share of the Karaganda region in the production of the metallurgical industry (52.8\% of the republican volume), including $49.7 \%$ in the production of ferrous metallurgy and $56.6 \%$ in the production of non-ferrous metals. The region occupies an important place in the republic in mechanical engineering and metalworking $[4,5]$. The leading enterprises in this industry are Mashzavod No. 1 LLP, Karaganda Machine-Building Plant named after Parkhomenko, Karaganda Foundry Machine-Building Plant JSC, Kargormash LLP, Karaganda Plant of Metal Products Imstalkon JSC, Tekhol CJSC, Kazchermetavtomatika JSC, Santekhprom LLP, Metal Products Plant LLP, etc., which have all the technical processing, having unique equipment and the necessary production facilities. The main areas of the machine-building and metalworking enterprises in the region are the production and repair of mining equipment, the production of building metal structures, manufacture of chemical, rubber and plastic products, etc. The main manufacturers of rubber and plastic products are Karagandarezinotekhnika LLP, Saranrezinotekhnika JSC, Voskhod LLP, which were created on the basis of the manufacturing facilities of the RTI plant in Saran. In the chemical industry, Temirtau Chemical and Metallurgical Plant LLP produces various types of chemical and metallurgical products, including calcium carbide, ferromanganese, ferrosilicon manganese, burnt lime [6].

The Karaganda region is one of the largest metallurgical and coal bases not only in our state, but also in the CIS countries. It is one of the richest in mineral resources that benefit the economy of Kazakhstan. According to statistics, the growth of industrial production of the Karaganda region for 10 months in 2018 amounted to $8.1 \%$ per annum. In the structure of industrial production of the region, a significant share falls on the manufacturing industry $(73.7 \%)$. Industrial production growth in mining and quarrying was $11.6 \%$, in electricity, gas and steam supply and air conditioning $-13 \%$, in water supply, sewerage, waste collection and distribution $-1.7 \%$. A significant share of industrial production in the total volume of the region falls on Temirtau (27.7\%), Karaganda (19.3\%), Balkhash (18.3\%), Zhezkazgan (14.1\%) and Abay region (4.9\%). An increase in production volumes leads to the fact that a large amount of harmful substances enters the environment, which creates conditions for an environmental threat emergence in the region.

\section{Materials and methods}

It is planned to use general scientific and special scientific methods in the article, i.e., analysis, synthesis, as well as historical-systemic methods of scientific research, which will allow the most complete disclosure of the goals and objectives of this work. It is planned to use an interdisciplinary approach, when methods of various scientific natural and humanitarian disciplines will be used to achieve the final result, which is very important in modern scientific research. 


\section{Discussion of the results}

\subsection{Ecology of the Karaganda region}

Emissions of industrial enterprises into the atmosphere of Kazakhstan are about 3 million tons per year, of which $85 \%$ is accounted for by the largest users of natural resources. The enterprises of the republic have accumulated about 25 billion tons of waste, including over 14 billion tons of technogenic-mineral formations, of which more than 1 billion tons of radioactive waste. According to the Agency of the Republic of Kazakhstan on Statistics, the annual amount of emissions increases by 700 million tons [7]. In a number of cities of the Republic of Kazakhstan, the concentration of pollutants in the atmosphere exceeds the maximum permissible level according to sanitary standards by 10 times. In the city of Karaganda, according to the stationary observation network, the level of atmospheric air pollution was assessed as a high level of pollution, which was determined by the value of Standard Index $(\mathrm{SI})=8.8$ (high level), maximum repeatability (MR) equaled $20.4 \%$ (high level) [8] (Table 1).

Table 1. Characteristics of atmospheric air pollution in the city of Karaganda.

\begin{tabular}{|c|c|c|c|c|c|c|c|}
\hline \multirow[t]{2}{*}{ Pollutants } & \multicolumn{2}{|c|}{$\begin{array}{c}\text { Average } \\
\text { concentration (gc.c.) }\end{array}$} & \multicolumn{2}{|c|}{$\begin{array}{l}\text { Maximum one-time } \\
\text { concentration } \\
\text { (gM.p.) }\end{array}$} & \multicolumn{3}{|c|}{$\begin{array}{l}\text { Number of cases of } \\
\text { exceeding the } \\
\text { maximum } \\
\text { permissible } \\
\text { concentration } \\
\text { (MPC) }\end{array}$} \\
\hline & $\mathrm{Mg} / \mathrm{m}^{3}$ & $\begin{array}{l}\text { Multipli } \\
\text { city of } \\
\text { excess } \\
\text { of MPC } \\
\text { c.c. }\end{array}$ & $\mathrm{Mg} / \mathrm{m}^{3}$ & $\begin{array}{l}\text { Multipli } \\
\text { city of } \\
\text { excess } \\
\text { of MPC } \\
\text { m.p }\end{array}$ & $\begin{array}{l}{ }_{\mathrm{MP}} \\
\mathrm{C}\end{array}$ & $\begin{array}{c}>5 \\
\mathrm{MP} \\
\mathrm{C}\end{array}$ & $\begin{array}{c}>10 \\
\text { MP } \\
\text { C }\end{array}$ \\
\hline $\begin{array}{l}\text { Suspended } \\
\text { substances }\end{array}$ & 0.113 & 0.750 & 0.300 & 0.600 & & & \\
\hline $\begin{array}{l}\text { Suspended } \\
\text { particles PM-2.5 }\end{array}$ & 0.090 & 2.576 & 1.414 & 8.837 & 586 & 38 & \\
\hline $\begin{array}{l}\text { Suspended } \\
\text { particles PM-10 }\end{array}$ & 0.077 & 1.85 & 1.426 & 4.754 & 280 & & \\
\hline Sulphur dioxide & 0.010 & 0.202 & 0.148 & 0.296 & & & \\
\hline Sulfates & 0.000 & & 0.010 & & & & \\
\hline $\begin{array}{l}\text { Carbon } \\
\text { monoxide }\end{array}$ & 1.112 & 0.371 & 10.631 & 2.126 & 16 & & \\
\hline Nitrogen dioxide & 0.032 & 0.807 & 0.130 & 0.650 & & & \\
\hline Nitrogen oxide & 0.008 & 0.138 & 0.067 & 0.167 & & & \\
\hline $\begin{array}{l}\text { Hydrogen } \\
\text { sulfide }\end{array}$ & 0.001 & & 0.047 & 5.888 & 6 & 2 & \\
\hline Phenol & 0.007 & 2.385 & 0.016 & 1.600 & 9 & & \\
\hline Ammonia & 0.010 & 0.240 & 0.016 & 0.080 & & & \\
\hline Formaldehyde & 0.008 & 0.791 & 0.022 & 0.440 & & & \\
\hline $\begin{array}{l}\text { Sum of } \\
\text { hydrocarbons }\end{array}$ & 1.090 & & 5.784 & & & & \\
\hline Methane & 0.810 & & 4.666 & & & & \\
\hline
\end{tabular}


None of the regions of the Republic of Kazakhstan is experiencing such a technogenic load as Karaganda. 370 enterprises of the region emit into the atmosphere more than 800 thousand tons of waste per year, which is the third part (more than 30\%) of all emissions in the republic. In terms of gross emissions of harmful substances into the atmosphere the cities of Temirtau and Karaganda occupy the 4th and 6th places among the cities of the CIS they and the 1st and 3rd places in the Republic of Kazakhstan, respectively. The damage to the natural environment in many industries exceeds the income from the exploitation of natural resources.

Indeed, the city of Temirtau today is one of the leading in the emission rate of harmful substances into the atmosphere. Here is a completely explainable reason for this fact. The main source of pollution in Temirtau and Karaganda region is the plant of "ArcelorMittal Temirtau" JSC (361.5 thousand tons per year) [9]. It is this plant that makes a huge contribution to exceeding the standards of maximum permissible emissions into the atmosphere, to non-compliance with the environmental requirements of the Republic of Kazakhstan, in violation of environmental management conditions. The history of the creation of this plant was not easy and interesting at the same time

\subsection{Attempts of creating a metallurgical base in Kazakhstan}

Technological modernization of industrial infrastructure carried out in the 1920s-1930s., which were the years of "socialist reconstruction of industry", made it possible to significantly change the proportions in the structure of the productive forces, giving a much greater specific weight to its industrial segment. But new industrial technologies were combined with the labor force in such a way that they brought the latter to the limit of physical and moral deterioration. After the war, the question of new breakthroughs in the country's heavy industry arose, since in all basic industries of the USSR in the first postwar year there was an absolute drop in production. In 1945, pig iron was smelted 59\% of the 1940 level, steel $-66 \%$, rolled metal $-65 \%, 62 \%$ of oil was extracted. Cars, tractors, combines, steam locomotives were manufactured 2-5 times less than on the eve of the war [9].

The questions of creating a powerful raw material fuel, energy and metallurgical base were arisen in the Kazakh SSR also in the second half of the twentieth century. The creation of metallurgical plants in Kazakhstan required the intensification of industrial exploration of the Atasu and Karsakpay iron ore deposits, the construction of the Sokolovsko-Sarbaysky mining and processing plant, the Karaganda metallurgical, Ermakovsky ferroalloy plants and other facilities was planned.

The coordinates of the Karaganda metallurgical plant construction (in Temirtau) had been already determined during the war years due to a rather favorable close location of the rich iron ores of the Atasuy deposit, coking coals of the Karaganda basin, Topar flux limestones, as well as various local building materials. During the Great Patriotic War, on April 25, 1942, the first government document on the future Kazakhstan Magnitogorsk was signed in Moscow: Resolution of the Council of People's Commissars of the USSR No. 576. It proposed to People's Commissar on ferrous metallurgy of the USSR I.F. Tevosyan to accomplish the following: "Along with drawing up a design assignment for the construction of the Kazakh metallurgical (processing) plant, develop proposals for the construction of a metallurgical plant with a full metallurgical cycle near Karaganda" [10].

In the order of the People's Commissariat of Ferrous Metallurgy of the USSR No. 93 of April 27, 1942, the following tasks were identified: "The head of the Main Directorate for Capital Construction, Comrade Petrukhin, and the directors of Gipromez (State Institute for the Design of Metallurgical Plants. - authors), Comrade Korobov and Yuzhgiproruda (State institute for the design of mining enterprises. - authors) comrade Volner are obliged to 
develop a design task for the development of the Atasu and Karsakpay iron ore deposits and, by October 15, 1942, submit proposals for the construction of a metallurgical plant in the Karaganda region for the production of iron, steel and rolled products for a report to the Council of People's Commissars of the USSR" [10]. Gipromez's specialists drew up project options, which were considered and approved by the Council of People's Commissars of the USSR on October 1, 1942. Years passed, but the construction of the plant did not begin due to the difficulties associated with the war and the post-war period. The question of the plant construction was again raised in 1946. On September 15, 1946, Deputy Minister of Ferrous Metallurgy of the USSR P.I. Korobov addressed the USSR Council of Ministers with a letter, which expressed a request for approval of the new production capacity of the plant and the site for its construction. In January 1947, the Council of Scientific and Technical Expertise of the USSR State Plan considered the project of the Karaganda Metallurgical Plant and issued a special resolution on this issue. The project of the plant, developed by Gipromez back in 1944, was approved on May 31, 1947 by the Resolution of the Council of Ministers No. 1837-481s. However, in 1948, a special commission found that the previously selected site for the construction of the Karaganda metallurgical plant (the left bank of the Nura below the dam) was unsuitable due to the high standing of groundwater.

By order No. 94 of April 5, 1946, the USSR Ministry of Ferrous Metallurgy appointed a commission (including a group of Kazakh scholars headed by Academician K.I. Satpayev, director of the Magnitogorsk Metallurgical Plant G.I. Nosov and others) to select the final site for construction of Karaganda Metallurgical Plant. The most suitable site (taking into account the "wind rose") for construction of the future giant plant was selected; it was approved by the Council of Ministers of the USSR by decree No. 14610 of October 4, 1948.

In July 1950, the deputy director of the Kasyuk plant reported on the main design organizations involved in the design of the Karaganda metallurgical plant ( 4 of them were in Moscow, 3 in Leningrad and 1 each in Tashkent and Kharkov):

1. Gipromez (State Institute for the Design of Metallurgical Plants), chief designer of the Karaganda Metallurgical Plant (Moscow, director of the institute comrade Belyanchikov).

2. Gorstroyproekt, general contractor for the design of housing, cultural, household and communal construction of the Karmetzavod in the Temirtau mountains (Moscow, director of the institute comrade S. I. Kolesnikov).

3. Gorstroyproekt, work on the design of trams, bridges, railways, signaling and communication (Moscow, Director of the Institute Comrade V.A. Grigoriev).

4. Vodakanalproekt, design of industrial water supply, sewerage, upland ditches and pumping stations (Leningrad, Institute manager Comrade B.A. Vinogradov).

5. Promstroyproekt, design of industrial construction objects of 3rd part of the general estimate for Kazmetallurgstroy, construction drawings for industrial structures and survey work (Moscow, director of the institute comrade V.I. Gerasimov).

6. Promstroyproekt, Leningrad branch, construction design for industrial structures (Leningrad, chief engineer of the institute comrade P.M. Igoshin).

7. Tyazhpromelektroproekt, design of power supply, substations, power transmission lines (Tashkent, manager of the institute comrade E.R. Chop).

8. Giprokoks, design of a coke-chemical shop (Kharkov, director of the institute comrade B. Molodtsev).

9. Giproruda, design of mines and quarries of nonmetallic raw materials (Leningrad, director of the institute comrade P.E. Sledzyuk) [11]. 


\subsection{The emergence of the Karaganda metallurgical plant}

In July 1957, the chief engineer of the project, Moisey Borisovich Klempert, arrived from Moscow for an extended retreat of the Karaganda Council of National Economy in Temirtau. He reported on the final project of the Karaganda metallurgical plant at this meeting, then to the Central Committee of the Communist Party of Kazakhstan (CPK) and the Council of Ministers of the Kazakh SSR (August 14), to the USSR Council of Ministers (December 17, 1957). The project of the Karaganda Metallurgical Plant was approved by the Government [1].

The main document for the construction of the Karaganda metallurgical plant was the "Design assignment for the construction of the Karaganda metallurgical plant. Gipromez, 1956", as a long-term creative work of about 50 design organizations of the country. In 1956, at the next congress of the party, a decision was made to create a third metallurgical base for the country and a task was given: "To put into operation at the Karaganda metallurgical plant two blast furnaces with a capacity of 1 million 390 thousand tons of pig iron per year and a continuous sheet mill”.

Since the end of the 1950s, the Kazmetallurgstroy trust, having freed itself from the construction of other facilities, concentrated all its efforts on the construction of the Karaganda metallurgical plant, and dozens of other specialized organizations were also involved there. On December 3, 1957, a solemn laying of the foundation of the first Kazakhstani blast furnace took place. On January 31, 1958, a Resolution of the Council of Ministers of the USSR was adopted on accelerating the construction of the Karaganda metallurgical plant and its raw material base. Since 1958, the construction of the plant's CHP and repair shops was in full swing. On February 24, 1958, concrete was poured into the foundations of air preheaters of blast furnace No. 1 .

In 1958 the plant became an all-Union Komsomol construction site. Construction orders were carried out by 389 enterprises, 75 Councils of National Economy of the country [10]. In the supply of equipment Bulgaria, the GDR, Hungary took part, along with other republics of the USSR. In the late 1950s, an average of 300 wagons of various cargoes arrived at the plant every day: equipment, mechanisms, construction materials. Construction organizations of the RSFSR and Ukraine sent thousands of experienced installers to the construction site. Only through the Ministry of Construction of the RSFSR in 1958, 7 specialized organizations participated in the construction of the plant. Representatives of the Academy of Civil Engineering and Architecture of the USSR, design institutes Gipromez, Giprokoks, Promstroyproekt, Moscow Institute "Orgstroy" helped builders to introduce new methods of production of local materials and products, organization of workers' labor and technical improvement of construction business. The Komsomol took patronage over the construction site and sent several thousand young men and women here. The main method of attracting labor was the Komsomol appeal, a significant replenishment came by free hiring. Some of the workers came from educational institutions and by organizational recruitment. In the middle of 1957, 1070 people were sent from Bulgaria to the construction site. The number of people, consisting of representatives of more than 50 nationalities, increased at the site of the plant every year. Table 2 [10].

Table 2. The number of workers at the construction site of Kazmetkombinat.

\begin{tabular}{|c|c|c|}
\hline № & Year & Number of people \\
\hline 1 & 1956 & about 2000 \\
\hline 2 & 1958 & 17683 \\
\hline 3 & 1960 & more than 20600 \\
\hline 4 & 1963 & 40900 \\
\hline
\end{tabular}




\subsection{Difficulties in plant construction}

However, the construction of the plant was extremely difficult. Examining documents from the 1950s in the Fund 698 of the State Archives of the Karaganda region allows us to trace what reasons hindered the process of building the plant. Let's consider the details of this construction. In 1955, there was an intensive correspondence with the Ministry of Ferrous Metallurgy, the Central Committee of the Party and the government of the country, where the reasons for such a protracted pace of the Kazakhstan Magnitogorsk construction were revealed. The construction of the plant was carried out by the Kazmetallurgstroy trust of the Ministry of Construction of Metallurgical and Chemical Industry Enterprises. Site selection and design work, as noted above, was started in 1943, construction work began in 1947. In the same year, the USSR Government approved the composition of the plant and the timing of the workshops commissioning (Resolution No. 4086-1401-s dated 23 / XII-1947). In particular, the date of commissioning of the first coke oven battery was determined in 1951 and the first blast furnace - in 1952 [12].

On November 29, 1954, the Ministry of Ferrous Metallurgy of the USSR made a decision to increase the capacity of the plant under construction for the production of pig iron to 2520 thousand tons, steel to 3000 thousand tons and rolled products to 2400 thousand tons. According to the plan, coke output was increased from 1,520 thousand tons to 2900 thousand tons. The construction cost was determined by Gipromez at 4.7 billion rubles. This decision determined the following composition of the plant:

1. Eight coke oven batteries with a coal preparation plant and complexes of chemical workshops (Designed by Giprokoks);

2. Sinter plant with a capacity of 3,000 thousand tons of fluxed sinter (designed by Mekhanobr);

3. Four blast furnaces with a useful volume of $1513 \mathrm{cbm}$ each ("Gipromez" project);

4. Nine open-hearth furnaces, including three furnaces with a charge of 250 tons and six furnaces -500 tons each;

5. Eight rolling-mill shops - blooming, rail-and-girder, sheet, seamless pipes, arc welding of pipes, cold rolling of sheet, tinplate and a rail fastening workshop;

6. CHP with a total installed capacity of 87 thousand $\mathrm{kW}$ (project by Leningrad branch of Teploelektroproekt);

7. Complex of repair work shops (shaped-casting, forging, mechanical metal structures and auxiliary shops).

The annual demand for the main types of raw materials was to be determined by the project:

A) 5300 thousand tons of iron ore, including for blast furnaces (with an iron content of $52.5 \%$ ) -4800 thousand tons and for open-hearth furnaces (with an iron content of at least $60 \%)-500$ thousand tons. The Atasu deposit was accepted as the ore base.

B) coking coals -8.4 million tons with their receipt from the mines under construction in the Dolinsky section of the Karaganda coal basin.

C) limestone - flux for blast furnaces and open-hearth furnaces - 1.6 million tons (with its receipt from the South-Topar limestone deposit) $75 \mathrm{~km}$ south of the city of Karaganda.

D) dolomite for open-hearth furnaces - 150 thousand tons. The project included Baikonur deposit in the Dzhezkazgan region.

E) molding sands -70 thousand tons. Production was planned from the Chaglinsky deposit of the Kokchetav region [12].

At the collegium of the ministry in 1955 , it was noted that "the construction of the Karaganda metallurgical plant, due to the underestimation of the importance of this construction, is being carried out extremely unsatisfactorily." "The first construction work on the construction site began only in 1951 (although, as noted above, the date for commissioning the first coke oven battery was already determined in 1951 and the first 
blast furnace in 1952). Until that time, all the activities of the trust were concentrated in the area of the Kazakh Metallurgical Plant and the existing old base of the trust. As it was noted in the memorandum, this situation was manifested as a result of the fact that the directorate of the Kazakh plant until 1952 performed the functions of the directorate of the Karaganda metallurgical plant, whilts the Kazmetallurgstroy trust believed that a new trust would be created for the construction of the plant. As a result, it ignored the work on the site by all means and strongly sought maximum costs at the expense of the Karaganda metallurgical plant in the area of the existing city of Temirtau.

As noted in the memorandums, the reluctance of the trust and the Kazakh Metallurgical Plant directorate to enter the site of the new plant resulted in the fact that significant funds (12.3 million rubles) were actually "dead" for the construction of the plant, laying of a construction base on the site the plant lagged behind unacceptably, and these facts became the main brake on construction. The Ministry of Ferrous Metallurgy and the Ministry of Construction of Heavy Industry Enterprises put up with this situation and did not take any measures until 1955 to change the situation.

The reports by the administration of the plan, the trust and the ministry reflect the main reasons for the long-term construction: "Despite the fact that the construction of the plant was started back in 1947, as of October 1, 1955, only 146 million rubles were spent. The site of the plant has not been prepared for construction, the construction base has not been completed, and auxiliary and intra-site railways and roadways have not been built. Also, the construction of the ore base of the plant - the Atasu iron mine, was carried out unsatisfactorily, and the construction of facilities for the nonmetallic raw material base of the plant has not yet begun. The design of the plant is being carried out unacceptably slowly: the new design assignment of the plant has not been completed, working drawings have not been issued for water supply, sewerage, heating, power supply networks, nonmetallic raw material base facilities, vertical layout of the plant site, master plan and transport. The location of the Kazmetallurgstroy Trust Office in the old part of the city of Temirtau, 10-14 km from the plant construction site, had a negative impact on the construction process. There are absolutely no specialists in the administration of the Kazmetallurgstroy trust with experience in the construction of large metallurgical plants with a closed cycle, therefore the trust does not even have a clear perspective on the nature and volume of construction. The staff of the necessary specialists is completely insufficiently staffed either in quantity or in quality" [12].

From the beginning of construction until October 1, 1955, the volume of capital work was carried out in the amount of only 146 million rubles $(41.8 \%)$ of the allocated 348.5 million rubles of capital investments, including for housing and cultural and domestic construction -62.4 million rubles, for the construction of the industrial base of the trust and temporary structures -36.8 million rubles, for roads, sewerage and electricity supply -20.2 million rubles. The construction of the main production facilities of the plant was not even started.

The reason for the underdevelopment of funds was, in the opinion of the plant's administration, due to the weakness of the Kazmetallurgstroy contracting trust, which was insufficiently equipped with construction mechanisms and vehicles, and the dispersal of human and material resources to a large number of construction projects located at a distance from each other. The large number and scattering of the construction projects entrusted to the trust had a negative effect: the trust, along with the construction of the Atasu iron mines, was building a number of facilities in the Akmola region at a distance of 250-300 km [12, sheet 119]. In particular, in addition to the Karaganda metallurgical plant, this construction trust was also entrusted with the construction of the SK plant, the Kazakhselmash plant and a number of state farms in the Akmola region, the Atasu iron mines and the access railway to them (57 junction - Karazhal) [12]. In addition, the 
construction was not provided, as already noted, with building materials, mechanisms and vehicles.

The plans of construction and installation works for the construction of the Atasu mine have not been fulfilled from year to year by the Kazmetallurgstroy trust. For 3 years - from 1953 to 1955 - the plan of construction and installation works by the trust was not fulfilled by $23-36 \%$, the construction of an access railway branch to the deposit was not completed. The unsatisfactory progress in the construction of the Karaganda metallurgical plant and the Atasu iron mine was explained in the ministry mainly by the low capacity of the Kazmetallurgstroy trust. Another reason was the lack of workers, i.e., in October 1955, at the construction of the Karaganda metallurgical plant and the Atasu iron mine, 2,200 people (36.6\%) were employed instead of the planned 6,000, of which 1,460 people were employed at the construction of the Karaganda metallurgical plant. The question of providing the construction site with labor was also far from being resolved. As at April 20, 1956, the trust numbered 2,067 workers in the main and 941 non-main production [11].

Due to the unsatisfactory management of the trust, the lack of work organization projects and the weak organization of construction work, even the existing number of workers was systematically idle due to the lack of materials (cinder blocks, fittings, timber, mortar), the lack of a prepared work front, insufficient flow, etc., which caused a large turnover of workers, reaching $70-80 \%$.

There was an unpreparedness of housing to receive the required number of workers to ensure the required pace of construction. It was noted that until 1952 the construction of housing facilities, social and cultural facilities and a construction base was carried out not on the construction site of the plant, but in the western part of the city of Temirtau, at a distance of 10-14 km from the site of the Karaganda metallurgical plant, therefore the effect of using these facilities for construction was very low, although the overwhelming majority of the engineering and technical staff and employees of the trust should be employed on it. The trust refused to build its own housing in the districts of the eastern part of the city directly at the site of the plant [12]. The Kazmetallurgstroy trust also built housing at its own expense without any prospects. The construction of the most important facilities, which predetermined such types of work as a construction base, a temporary industrial water pipeline with water intake and sewerage of residential areas, a construction base and a plant site, was delayed. Due to the unjustified delay in the construction of the industrial water pipeline, the trust used scarce drinking water for construction purposes, systematically leaving the Temirtau residents of quarters 98 and 99 without water. [12].

The Minister of Ferrous Metallurgy of the USSR A. Sheremetyev, reporting on the progress of construction to the Council of Ministers, wrote that the capital work plan for 1955 provided for the completion of construction and putting into operation: a construction base, a 110 kilovolt power transmission line with a step-down substation, the TemirtauKaraganda highway and 14 thousand sq. meters of living space. But the timeframe for the commissioning of the launch facilities established by the plan was disrupted, and none of the launch facilities was completed. 14 thousand sq. meters of living space, which was set out in the plan, not a single square meter was introduced within 9 months [12].

Again, new decisions were made on new terms for the completion of construction work and the commissioning of the existing ones. The draft five-year plan for 1956-1960, developed by the USSR Ministry of Ferrous Metallurgy, provided for the completion of construction and commissioning of the main facilities of the Karaganda Metallurgical Plant in the following terms, i.e., blast furnaces: No. 1 with sinter plant - 1958, No. $2-1959$, No. 3 - 1960; coke oven batteries No. 1-2 with a coal preparation plant -1958 , No. 3-4 1959; open-hearth furnaces No. 1-2 - 1959. No. 3-4 - 1960; blooming - 1959; sheetrolling workshop - 1960; CHP - 1957-1960 [12]. 
However, despite the decisions of various levels of the union center (from orders of the minister and decisions of the collegium to the decisions of the Central Committee and the Council of Ministers), the situation has not changed. The construction was going badly, the tasks were not fulfilled, the construction deadlines were disrupted.

The fund's cases abound in various kinds of letters, petitions and memoranda to the highest authorities of the republic and country. In 1953, the secretary of the Karaganda regional party committee $\mathrm{H}$. Bakauov, as well as the director of the plant T. Shevchenko wrote to the first secretary of the CPK Central Committee Zh. Shayakhmetov about the problems in the construction of the plant [12]. In the same year, at the Party conference, the director of the plant $T$. Shevchenko raised the question of the position of the secretaries of the Temirtau city party committee (in particular, Shepelev and Konakbaev), who slowed down the construction of the plant, objecting to the construction of Karmet by the Kazmetallurgstroy trust [11]. On April 16, 1956, the secretary of the regional committee Yakovlev and the director of the plant Yashchenko sent L.I. Brezhnev a government telegram about the threat of disruption to the construction of the plant due to the lack of technical documentation of facilities for 1956 [11]. At the beginning of 1957, the director of the plant B. Yashchenko wrote to the first secretary of the Central Committee of the CPSU N.S. Khrushchev with a request to assist in strengthening or creating a new construction organization, since the existing trust was neither quantitatively nor qualitatively ready for the tasks set for the construction of the plant. On February 4, 1957, he sent a letter of similar content to the first secretary of the CPK Central Committee L.I. Brezhnev [11]. However, the construction issues were not resolved, despite the decisions of the center to create a new base for ferrous metallurgy in the republic.

When building giants of industry, the administration of the republic ignored the interests and needs of the population, forcing the construction of industrial facilities. Ignoring the social and other problems of workers during the construction of the "Kazakhstan Magnitka" led to mass unrest in August 1959 in Temirtau; in a collision, the authorities allowed the troops to use weapons to disperse the workers, which led to the death of people. After the events of 1959 in Temirtau, supplies of building materials and equipment stabilized for some time, and social and domestic problems were partially resolved. In fact, the Temirtau events drew Moscow's attention to the protracted construction and contributed to the solution of the main issues of the Temirtau long-term construction.

The main ore base of the Karaganda metallurgical plant was the Atasu iron ore region, where two open pits were commissioned, i.e., Bolshoi Ktai and Western Karazhal. The largest was the first one, which was put into operation in 1961 at full capacity, in 1962 it had already produced 202 thousand tons of ore with over-design capacity. By 1965, the extraction of iron ores by the Atasu Ore Administration in comparison with 1958 increased by more than 3.5 times [9].

In June 1960, the first blast furnace was blown in at the Karaganda Metallurgical Plant, and the first pig iron was produced. In December 1960, the first coke oven battery was commissioned, and the production of Kazakhstani coke started.

However, even by 1965 in ferrous metallurgy, out of 24 facilities put into operation over the previous seven years, the design capacities of blast furnace No. 1, open-hearth furnaces No. 1 and No. 2 at the Karaganda metallurgical plant were not mastered [9, p. $248]$.

\section{Conclusion}

Long-term construction, typical of Soviet post-war industrialization, lasted for almost two decades. In general, the Soviet industry was extensive and capital-intensive, since the only factor determining the quantitative dynamics in the industrial development of the republic 
was the growth of investment in the industry of the region, with practically no adequate return. However, the situation with the long-term construction of the plant has fully paid off over time. This is due to the presence of large reserves of raw materials for the production of refractory materials, the location of large ferrous metallurgy centers in the region, advantageously located for the development of iron ore, manganese deposits and coking coals, the possibility of providing water (Irtysh-Karaganda canal). Today the Karaganda region is one of the main branches of ferrous metallurgy in the republic. By the decree of the Government of the Republic of Kazakhstan, the Karaganda Metallurgical Plant since November 17, 1995 became the property of Ispat Karmet JSC, which was re-registered in Mittal Steel Temirtau JSC in December 2004, and ArcelorMittal Temirtau JSC since September 6, 2007. Today Karmetkombinat has become a part of a global steelmaking company in the world with a production volume of 70 million tons of liquid steel. The company maintains a consistent course of equipment modernization and production technology improvement.

An excess of maximum permissible emissions standards into the atmosphere, a constant violation of environmental standards during the discharge of domestic wastewater and waste management are recorded in the activities of the Karmetkombinat. For environmental violations, the plant annually pays the state a minor fine for it in the amount of up to 1.7 billion tenge. Due to this fact, this environmental problem in the region caused by the plant functioning is permanently unsolved, which allows the company to keep violating environmental standards.

\section{References}

1. Zh.S. Mazhitova, Asian Social Science 10(20), 129-136 (2014)

2. History of Kazakhstan (from ancient times to the present day). Vol. 3. Almaty: Atamura, 768 (2000)

3. Z.G. Saktaganova, Zh.S. Mazhitova, Y.N. Aimakhov, B.A. Dosova, L.I. Zuieva, S.S. Kassimova, European Journal of Science and Theology 14(1), 103-114 (2018)

4. T. Alimbaev, Zh. Mazhitova, B. Omarova, B. Kamzayev, K. Atanakova, E3S Web of Conferences 157, 1-8 (2020)

5. T. Alimbaev, B. Omarova, B. Abzhapparova, K. Ilyassova, K. Yermagambetova, Zh. Mazhitova, E3S Web of Conferences 175, 1-9 (2020), https://doi.org/10.1051/e3sconf/202017514008

6. T.B. Kazbekov, G.N. Rystambayeva, Prospects for the development of manufacturing enterprises in the Karaganda region, Proceedings of the international scientificpractical conference «The new economic policy - the basis of sustainable development of the region», Karaganda: Printing house of KEU Kazpotrebsoyuz, 351-354 (2016)

7. D.A. Aitzhanova, A.K. Omarov, Ensuring the sustainability of economic development in the conditions of environmental restrictions, Proceedings of the international scientific-practical conference "The new economic policy - the basis of sustainable development of the region", Karaganda: Printing house of KEU Kazpotrebsoyuz, 323328 (2016)

8. A.T. Mergenbaeva, I.E. Kozhamkulova, The impact of refineries on the ecological and economic state of the Republic of Kazakhstan, Proceedings of the international scientific-practical conference "The new economic policy - the basis of sustainable development of the region", Karaganda: Printing house of KEU Kazpotrebsoyuz, 307312 (2016)

9. Z.G. Saktaganova, Economic modernization of Kazakhstan. 1946-1970 (3rd ed. Karaganda: Publishing house of KarSU, 365, 2017) 
10. State Archive of Karaganda region. Fund 698. Inventory of documentary materials of permanent storage period 1943-1963

11. State Archive of Karaganda region. Fund 698. Inventory 1. Case 6.

12. State Archive of Karaganda region. Fund 698. Inventory 1. Case 23. 